\title{
Shaping Stories: Linking Images Through Time and Space
}

\author{
Rachna Gilmore (C2001
}

It is such a pleasure to address an audience openly celebrating children's literature, where no one is ashamed of delighting in children's stories, and where no one wishes to ha ve grown-up covers for children's books, as though reading children's literature is a slightly dirty habit that must be hidden at all costs.

I also write adult fiction, under a pseudonym Rachna Mara. My one collection of adult short fiction, Of Customs and Excise, came out in 1991. When I meet with other writers, particularly those who write adult fiction but not children's stories, I almost inevitably get probed, either directly or obliquely, as to why it's been so long since I wrote adult fiction.

Some people go for the flattering approach: "I hope you're not going to give up writing adult fiction, Rachna. I'd love to see what else you could write-a novel maybe? Of course," they continue, "I know you've been writing children's stories, and I know there have been some awards and well..." Often, at this point they trail off before rushing on, "Not that children's writing isn't important, but, it's just, well, your collection of short stories was so good."

No one has come right out with it, but what they' re thinking is: when are you going back to the stuff that matters? When are you going back to the Grown-up stuff? Yes, yes, we know children's writing is necessary, but all those picture books, well, anyone can dash them off and so...

But children's literature is so much more than a lower or less-skilled or less-insightful version of adult fiction. We know this because if we are asked to remember books that resonate within us, we almost always come up with some titles that we have read as children. The impact of children's fiction, of books we read as children, reverberates through our lives far more than the books we read as adults.

I certainly do not consider writing for children a lesser form of my art. The process of creating is the same, whether it's writing for children or adults.

It seems to me that as writers, we are co-ordinators of images, directing the mind towards a new way of looking at a particular situation in life. We examine the plethora of images, experiences, ideas, thoughts, feelings and dreams in our lives - the whole mess and mass of them that swirl and flow disconnectedly in the untidy way that life works — and we select certain ones, linking them to tell a tale. We juxtapose them in new ways, weaving strands of seemingly unconnected images from far and wide to say: look do you see how it works? Did you think of it this way? For me, personally, to begin any piece of writing is an act of faith. I have to trust the links my 
heart and mind and soul and spirit make. I have to honour the images that surface, and trust that the ideas that want to be connected, that spring from somewhere deep inside me, are there for a reason. It is very much a process of discovery, with false starts and wrong turnings and some dead ends before the way becomes clear, and the story flows. I don't think the initial leap of faith is any easier even after several attempts. I see it as climbing up a tall tree in the woods, taking a deep breath and jumping off without a rope, without a parachute, but jumping off knowing that I will land all right. And I always have.

Often, the ideas and experiences we link and weave into stories have been submerged within the body, locked or waiting. Just waiting for the right moment to surface. And I don't exactly understand what the triggers are, or when or why certain ideas seem to ripen-but ripen they do, and then surface. And honouring that process, and having faith in it, involves accepting that the images, thoughts and ideas that surface with such ringing insistence, are the ones that must be investigated, that they warrant my spending a couple of years or more trying to find the links that fit.

Most people would agree that many of these ringing images and experiences, the ones that have the most resonance and clarity, are created and locked in during childhood. Not only do they surface and impact on our day to day lives, on the kind of people we are, but also on the kind of stories we write, and why we write.

I'd like to share here some of the images, experiences, landscapes, stories and books that have left resounding echoes within me, and which have nudged and guided me towards a writer's life. And it seems to me that in telling that story, I am doing exactly the same thing that I do when I write fiction-I'm linking some specifics to tell my tale. I could select other images and echoes from my life and tell an entirely different tale. It is my choice of which particular nuggets I select to link, that direct the outcome of my story.

For instance, I could build my story around images of how, when I was a child, I was influenced by the fact that my mother was a doctor; and how I used to watch her lining up the kids in our neighbourhood to give us various vaccination shots; and how impressed I was by the importance of my mother as she did this; and how I studied the sciences in school because, of course, I was going to be a doctor, too.

All this is true, but I'm not a doctor, and so that is only part of the story. There were other images and experiences that had more lasting impact on me, although I didn't always know it at the time. Experiences that shaped and influenced a certain desire and ability to listen to an inner song-a song I didn't even know was growing and gathering force inside me.

One of the strongest images I have of story in my life is of my grandmother telling me tales. I was born in India and lived there until I was fourteen, when I moved with my family to London England. In India, we lived in Bombay, which is a big city, dirty, crowded, noisy as big cities are; and my grandparents lived in Jaipur, in Rajasthan, which is a dry desert state. My grandmother 
was a small serene soft-spoken woman. She and my grandfather lived an orderly life that was tied to the natural rhythms of the day. My grandmother wore simple cotton saris, mostly in subdued colours-off-white, pale yellow, soft shades of green, blue. Her grey hair was always tucked in a tidy bun at the nape of her neck, and she had even features and a small straight nose, which I envied even as a child, regretting my own rather more assertive honker. Mostly what I remember about her is how small she was, and how peaceful and deliberate in all that she did.

I remember one particular visit. I don't know for sure how old I was, perhaps 7 or 8, but I know that my mother's siblings were there, too-her brother and sister-each of whom had two children. My grandparent's house was a large sprawling brick structure, whitewashed a mellow yellowish-ochre colour, and built around a huge central courtyard which was tiled, I think, with red stones, and open to the sky. And it was in that courtyard that we slept-partly because there were so many of us, but mostly because it was hot, being I believe, the summer, which is a whole different story from the heatwaves we complain about here in Canada.

My grandparents rented a whole bunch of charpoys, which were cots, or beds, consisting basically of a wooden frame with thick jute rope woven across to form a base, over which was placed a mattress. Being middle class Indians, my grandparents had servants as was the norm, and each night the servants would set out the cots on the courtyard, put on the mattresses and sheets and, I think, also a mosquito netting around each cot. In the morning, the process was reversed, and the cots were piled one on top of the other. This was a huge delight to me and my cousins. There were six of us; my brother and I, and four cousins. We'd climb atop the piled cots, kings and queens of all we surveyed, and eat our breakfast there before the heat of the day chased us indoors. Of course, we played and fought together, like most kids. And often, often, we would run to my grandmother and beg her for stories.

I regret infinitely that I don't actually remember any specific story that my grandmother told us. All I remember is us kids gathered around her, sitting on mats on the floor, or on the cots, somewhere in the shade of the courtyard, as she spun her magic. The stories were, I think, Aesopish tales, many involving animals, likely with some kind of lesson or moral attached; and my grandmother told them in Hindi. It's possible that I don't remember any of them because her repertoire was so vast that she rarely repeated them. Or perhaps she made them up as she went along. I remember clearly, though, that we'd beg for more and more stories, and somehow, from somewhere inside her small body, she would bring out yet another one-a seemingly endless supply of delight.

The only story I recall parts of was one in which there was some scatological reference. My cousins and I were hugely, hysterically amused by this, because my grandmother was so mild and restrained, so naturally refined, that any vulgar reference from her was quite unusual. But of course, it was not gratuitous-I think the reference was to some man who was so scared that he soiled himself. I still remember my grandmother's shy, soft laugh as she told us this. But we kids laughed immoderately over the image, and retold that part of the story to each other with enormous glee. And although I don't recall the specifics of my grandmother's stories, what was locked into me was the feeling of safety as she told us stories. The rightness of being still around 
her, listening. The orderly energy emanating from her. The security and love.

And what was also locked into me was the shape of the stories she told. She was obviously a gifted story-teller. She knew how to keep our attention, she knew where the story needed to be more exciting, and how to pique our interest and sustain it. She must have, because otherwise, we wouldn't have asked for more. She taught me the shape of stories, although I didn't know it at the time. And even though the stories are lost, the way of framing them, of developing a satisfying emotional arc, is ingrained into every cell in my body.

Of course, when we are children we don't see any aspect of our lives as being unusual or out of the ordinary. Everything is just a simple given. So I don't think I considered myself lucky to have a grandmother who told us stories, or understood the value of it. It just was.

There are two other images I associate with the time spent around my grandparents. They don't have to do with story directly, but somehow, I think they nurtured and cultivated a sense of wonder, as well as wondering, in me-both of which, I believe, are necessary impetuses for the exploration that is writing.

One of those images is of being at my grandparents' house and going out to the courtyard at night, to gaze up at the night sky. Such a vast bowl of night, with the stars like dust, so many, so many more than I could possibly have imagined living in a big city as I did. I remember gazing up at the night sky, at the hugeness of it all. There were no specific questions, just wonder. An allencompassing awe.

The other image is of early mornings spent with my grandparents. Both my grandparents were very spiritual people and they retired to bed early at night and awoke early, for their morning meditation rituals. When they visited us, or when we visited them, I, too, would wake early to spend time with them. I don't quite remember where, but I do remember several times during the dark stillness just before dawn, going with my grandmother to a nearby tree which nightly dropped an abundance of small, fragrant, white flowers. I remember gathering them up in my skirt. They weren't jasmine flowers, but something very similar. The fragrance of jasmine is much like that of mock-orange, only sweeter-it has a piercing sweetness that is like a rush of cool water and intense sunlight all at once.

After we'd gathered these flowers, we'd go back to the house and my grandmother would string them into a garland for my hair. I'd wear the garland around my pony tail, delighting in the aura of sweetness. Then, with the dawn, the silence would be broken by the sounds of birds chirping, of people stirring, the clang of pots being taken out to cook breakfast, taps turning on, perhaps a radio playing Indian film music. As the blessed cool of the morning was quickly smothered by heat, the flowers in my hair would fade. First, they'd droop a little, then the white petals would tinge brown at the edges, until, by the afternoon, the garland was ready to be discarded. A fitting metaphor for the stillness and potential of those mornings being used by the bustle of the day.

But the stillness of those mornings remains within me. It is a memory I treasure deeply. The early 
morning was such a perfect time - a time of wonder, serenity, ease. A time to reflect. A time of infinite possibilities, with the day ahead a yet untold tale. I don't exactly understand how, but I know that it is the stillness of those mornings, the stillness of the night sky, the powerful potential inherent in both, that is the source of the energy for creating stories. Because the delight I feel when I'm caught in the flow of creating story, is the same as the delight of those mornings.

Even when I returned with my family to the city of Bombay after those visits, I valued the stillness of the morning, although I could no longer relish the night sky. My friends and I would wake early and go for what we called our "early morning walks."

B ombay is on the west coast of India, and we lived fairly close to the ocean. I think it was about a 30-40 minute walk to a place called Nariman Point, which is now all developed with high-rise buildings, but back then, was a peninsular of rocks jutting out into the Arabian Sea. We'd try and get there before the sunrise, and watch the translucent sky lighten, lighten, and we' $d$ wait for the first rays of the sun to set the water dancing and blazing with light. I distinctly remember the feeling I had when I returned from those early morning walks - a sense of escape, of having been away a long time to a remote place. A sense of newness, of being temporarily free of the habitual filters through which I viewed life; and most of all, a sense of being able to embark in any new direction and undertake anything. A powerful and pure feeling.

The ocean has always played a strong role in my life-its sounds and echoes are locked in my body. Those visits to the ocean, the time I spent gazing at the water, listening to the waves lapping and slapping against the rocks, created a force that guided my future. To paraphrase Meridel Le Sueur in The Ancient People and the Newly Come, bodies reflect their landscapes, and each impacts on the creation of the other.

I would go further to say that the landscapes locked within our bodies pull and influence us, and are an abiding and significant force in directing our lives.

Certainly, that was the case for me. Perhaps in part it was the tug of the ocean that brought me to Prince Edward Island from England, after I graduated from University. But it wasn't entirely that. There was another significant factor that motivated both my coming to Canada, and my becoming a writer-another landscape that played a part.

It was in my school in India, and I think when I was in Standard 4, which is the equivalent of Grade Four here, that I first encountered a book that has now become an old and cherished friend. My school was run by the Anglo-Scottish Education Society. It had the rather grand title of Cathedral and John Connon School. It was a private schoo—a hangover from Colonial daysand considered to be the best one in Bombay. The girls' school and boys' schools were separate back then and we wore school uniforms - grey dresses over white shirts. The grey dress was a smock like affair with broad pleats falling from a yoke. We wore sashes tied around the waist like ties. The colour of the sash depended on the house to which we belonged. Unlike Harry Potter, there was no sorting hat, and we chose the house we wished to be in. I chose Red house, so wore 
a red sash. It just so happened that in my class, there were more girls in red house than any other. I was never one of the really cool kids. I guess I was somewhere in the middle, not a total loner, but not one of the acknowledged leaders, either.

My class was quite large-possibly over thirty girls. But what a wild bunch we were. We had the reputation of terrorizing teachers. Of blithely flouting authority. We were a bright group of girls, full of energy, and, I'm ashamed to admit, complete disregard for the feelings of teachers. I suppose that this was partly due to the classist society in which we lived. In any case, I suspect that when the year began, the teacher who drew the short straw and was assigned to our class groaned inwardly, and resigned herself to a torturous year. That is if she were dignified. If not, she probably fell to the staffroom floor writhing, flailing and screeching. Of course, not all teachers were treated in the same manner-in the uncanny way of children and wild animals, we knew which teachers we could get away with sassing.

This particular year, our teacher was an Englishwoman, Mrs. Chaubal. She was small, tidy, with reddish hair, a slight, straight nose and she wore tailored clothes. To my complete fascination, she always had her red hair up in a bun, a French roll, the ends of which were tidily invisible. Back then I had long hair, down to my hips, and I could never figure out how Mrs. Chaubal kept that bun so neatly in place.

Some time during the school year, Mrs. Chaubal began the habit of gathering us around her chair first thing in the morning, and reading to us. Perhaps she thought it would have a salubrious effect on us, channel our energies constructively. I can't remember what she read apart from this one book. Sitting crammed with a bunch of girls squirming against each other in the gathering heat, the overhead fan whirring, lightly stirring our hair, our white sneakers adding a somewhat rubbery overtone to the other classroom smells of cleaner and chalk dust - that's how I first became acquainted with Anne.

I'm talking, of course, about Anne of Green Gables, by Lucy Maud Montgomery. I suppose it says something about the skill with which Mrs. Chaubal read, that we were entirely quiet during her reading. She was adroit at skipping over any long descriptive passages that might make us fidgety. I remember clearly her reading out the part where Anne asks Marilla if she could call her Cordelia. Or failing that-Anne with an e. Mrs. Chaubal read with animation, and at one point, during Anne's intense speech, Mrs. Chaubal inadvertently spat. This would have caused enormous hilarity and scorn under any other circumstance, but I don't think anyone cared as we listened to this book. From the moment Anne whacked her slate down on Gilbert's head, I had to know what was going to happen. Would they ever be friends? I had a stoical, don't-care, tomboyish persona, which I had carefully cultivated, but internally, I delighted at the sniff of romance.

Mrs. Chaubal never finished reading the book that year-we must have run out of time, or else we misbehaved so badly that she stopped. But I insisted on going to the bookstore and finding the book. I had always been a voracious reader, and I spent almost every paisa and rupee of my pocket money on books - mostly second hand to maximize the numbers I could purchase. I couldn't find a second hand copy of Anne of Green Gables, so I bought a new one with my 
precious horde of money and devoured it with delight. I was thrilled that there was a sequel, saved my money for it and bought and devoured it too. I bought all the Anne books the bookstore carried, and read them over and over, until the characters were as familiar to me as close friends. I still have some of those books I bought so long ago. One of them, a copy of Chronicles of Avonlea, was given to me as a prize in my school. The end of year awards always comprised of books. Apparently in Standard 5, when I was ten years old, I worked diligently enough to get honours. What a splendid way to reward kids-with books. The year after, when I did well in my Standard 6 exam, my mother bought me as a reward, at my request, Anne of the Island. It is dated as having been given to me on the $5^{\text {th }}$ of May, 1964, when I was ten and a half. I didn't realize at first that the world created by L.M. Montgomery was based on a real place. I had no idea it was in Canada or that Prince Edward Island existed. I'm not entirely sure how, or even when, I learned this, but I remember the electric charge of discovery when I found that PEI was real, in this world-a place I could actually go to some day. And I knew with the kind of ringing certainty that comes when the future seems to reach back and yank you to the course you inevitably have to follow, that I would go there one day.

Many of you are teachers, librarians, parents. You don't always know the impact you have on the children you deal with daily. You don't always receive thanks for your work or the validation you deserve. Often, it must be disheartening to encounter obnoxious kids-much as I expect I was as a child. But I hope you can take heart from my story. You may never know who you inspire, or when you inspire, or how you inspire. But be assured, that inspire you do.

I'm sure Mrs. Chaubal never considered that the simple act of sharing a book she loved would have such far-reaching impact on one girl sitting in front of her. Who knows how many others were influenced by that book, or by others she read aloud? I don't know with absolute certainty if in fact Mrs. Chaubal did have a small straight nose and red hair. Quite possibly she did. Or was it that as she read about Anne, Montgomery's vivid description transposed over Mrs. Chaubal, so that now, when I think of Mrs. Chaubal, I think of her as looking like Anne?

Isn't it extraordinary how books and words and stories cross time and cross distance in less than the blink of an eye? The power they have to negate time and space? They give us more than mere insight into other cultures and places and landscapes - they let us live them. Lucy Maud Montgomery, sitting in her room at her grandmother's house in Cavendish PEI at the early turn of the previous century, chafing at the sterility of her existence, frustrated by the self-imposed duty of caring for her stern, aging grandmother, who was, for the most part, not a kindred spirit, escaped into a world of greater delight when she created Anne. Amongst other things, Maud wove into the story her love of the Island landscape. It is palpable in the pages, it breathes and swirls in the way in which Anne gazes at the fields, as she wanders through Lovers Lane, as she runs past the Dryad's Bubble and walks through the Birch Path with Diana on her way to school.

When Anne wakes up that first morning at Green Gables, she goes to her bedroom window and looks out. She smells the dizzy fragrance of nearby lilac trees, glories in the cherry and apple orchards, thick with blossoms, and gazes with delight at the green rolling fields, etched with fir and spruce, and at the distant, tantalizing glimpse of a blue sea. 
The images of this landscape fascinated and intrigued me. Living in the heat of Bombay, in a house in which every single room had an overhead fan - a complete necessity - I had never seen snow, except during one trip to the Himalayas. I had never snowshoed as Anne did, never experienced seasons, other than muggy summer, the months of rain, often torrential, during the monsoon season, and the marginal relief from heat that came with the so-called winter, where, at most, one might need a light cardigan.

But as I read and re-read Maud's books, the love of the land, the love of Prince Edward Island, the landscape that Anne relished and gloried in, crept into my skin and bones, and worked into every cell in my body.

I also indirectly imbibed the Presbyterian attitudes and ethics of the Scottish settlers who came to Canada, and experienced the somewhat cloistered and strict world of Maud and Anne, of rural life in Prince Edward Island during the latter part of the nineteenth century. I experienced the delights of walks through fragrant spruce and pine woods, the thrill of going down cellar for apples, the way lit only by a candle. I experienced the cosiness of a small knit community, and all the gossip that eddied through daily life. I don't think back then, though, I recognized the rigidity and intolerance of some of the views expressed in Montgomery's books, which were a reflection of her times, or really understood the flip side of that small community, nor yet the power that gossip had to wound and destroy. I was simply fascinated by the closeness of Anne's world and community. It was one I rarely encountered, except perhaps with my grandparents, because my life in Bombay was that of an upper-middle class child in a big city, which, in that place and time, meant having servants to take care of all the chores, so our parents were free to go out as often as they pleased.

But Montgomery's books and landscape had a lasting impact on me. When I graduated from University in England in 1974, I decided to travel. Canada appealed to me for a variety of reasons - it seemed so full of possibilities, and it seemed to be more culturally tolerant than the England I was then living in. Of course, if I came to Canada at all, it would have to be to Prince Edward Island. I'd lived in big cities all my life, but Montgomery's descriptions of PEI had woven into my body and become my landscape. When I read the books, I don't recall being particularly conscious of lingering over Montgomery's at times flowery descriptive passages. I may even have skimmed over them, to get to the good part, to see what Anne would do ne xt, if she'd ever forgive Gilbert Blythe. But enough of those passages permeated into me anyway, and I think what I longed for was the delight that Anne felt at the beauty of her world. It struck me as being impossibly romantic and perfect to do some of the simple things Anne did-walk through the woods entranced by mayflowers and violets. What were mayflowers and violets? I wanted to see them myself, experience that delight, too.

So I came to PEI. In the extreme earnestness and dignity of youth I was probably not too keen to admit back then that a kids' book was a significant motivator to my being there. I remember being embarrassed by it when someone brought it up. But the rural landscape did indeed delight me- 
after all it was familiar, already within me. And not surprisingly, the landscape of PEI that most appealed to me was the north shore of the Island where Maud Montgomery had lived. This was quite apart from the association with all the Montgomery sites and the touristy stuff one finds there, some of it rather exploitive, and not always tasteful. Best of all, the ocean was there too, waiting for me-calling and recalling early mornings spent gazing at a different body of water from a jut of land in Bombay.

The year I asked for and received Chronicles of Avonlea for Honours in Standard 5, I also received another book. I didn't ask for this-I expect when I saw it, I thought the title was dull and pretty sucky. The book is dated as being given to me on the $7^{\text {th }}$ of February, 1964, when I was ten and a half. I can't remember if I devoured it with eagerness soon after getting it, or whether it languished on my shelves for a while as I read the more interesting Biggles books by Captain W.E. John, the William books by Richmal Compton, the Enid Blytons, even Jane Eyre and Pride and Prejudice. But eventually I did pick it up and read it. It was Little Women by Louisa May Alcott.

I do know that right away I was caught up in the world of the March sisters, and I identified strongly with Jo. When I read about Jo's efforts at writing stories, something inside me whirled with excitement. I don't expect I articulated it clearly at the time, but I think that that is when the idea and possibility of being a writer was born. What an enchanting, wonderful way to earn a living, of living! The idea appealed to me enormously. I loved to read, had always done so. Books were very likely an escape for me, a refuge - but I had always preferred the world of the imagination to the more prosaic humdrum world of reality.

What could be better than honouring the truth of that imagination by giving it tangible form through writing?

So, as I read Little Women, the seed was planted, the seed of being a writer. I read the book and its sequels for the sheer delight of them, eager to find out if Jo would or would not marry Laurie. Like countless others, I cried when Beth died, was disgusted that Jo settled for the portly $\mathrm{Mr}$ Bhaer.

And I was enormously impressed and fascinated by Marmee - that mythical mother who never lost her temper. She was outside my experience in real life-none of the mothers I was acquainted with, mine or anyone else's, was remotely like her. When I became a mother, I certainly was not like that either, much to my secret dismay, at first. I suspect, that at some level, my first book My Mother is Weird is an antidote to her. I also have tongue in cheek references to Marmee in my new young adult novel, A Group of One, due to be published by Henry Holt in June 2001.

So Little Women became an old friend, like Anne of Green Gables, to be read and re-read and treasured. 


\begin{abstract}
As a child, during one of my infrequent fits of organization, I decided to sort my books and categorize them in order of importance. I no longer have my first copy of Anne of Green Gables, having in a fit of utter stupidity given it away when I left India, but I do still have Anne of Avonlea and it was marked as Number Two, with this little verse written on the front page by me:
\end{abstract}

The grass is green

The rose is red

This book is mine

'Til I am dead.

In some of my other books, I added this:

P.S. Even after I'm dead.

Chronicles of Avonlea was number 3 and Anne of The Island number 4. Obviously, Anne of Green Gables was number 1. Little Women came in at 16. But although the books from four to fifteen are forgotten, Little Women is with me still.

During those years in Bombay, the first fourteen of my life, I saw no TV, because there wasn't any in India at the time. My favourite activity was, of course, reading, but there was still lots of time to hang out with my friends, play games, sketch, paint, mess around with crafts. It's amazing the time that is freed up when we don't have that box dictating our lives. Books were such an integral part of our lives, that my friends and I derived many ideas from them. Living in a city, I could not relish, as Anne did, walks in the country־but I could at least have a story club as she had.

And so, around the time I was twelve or thirteen, inspired by Anne's story writing club, and by Jo's fits of scribbling, I persuaded my friends to form a writing club. There were four of us, and for some reason I cannot remember, we called ourselves the Lulu Club. We were to meet at regular intervals, each having produced a piece of writing on an agreed upon topic or theme. I don't have the originals of any my writings, but later, after I left India, I wrote to my one of my friends, Padmini, and asked her to copy out some of the stories and send them to me. She did. Back then there were no photocopiers, so the fact that she hand wrote as many as she did, is a sign of her extraordinary faithfulness and generosity.

Not all our stories were gruesome and tragic as Anne's stories were, but we did have our share. One particular gem written by me begins in this charming fashion:

Blood! God! How it had gleamed! Old Meg shivered and licking her shrivelled lips darted a look behind her. How she wished she had never killed Crackpot Casey. How well she remembered that scene. He had cried for mercy but she had shown him none and he had died with vows of revenge which she had thought would never come. And now...she shuddered as she recalled the blood. I don't know exactly when the idea of becoming a writer grew upon me, but I do remember the day it surfaced into my conscious mind. I was about twelve or so, really thinking about it, and I felt the idea settle and lodge within me with the satisfying ching of something falling or slotting into perfect place. I lived on the top floor of a three story Georgian mansion-a leftover from the 
Colonial days. It was an old building that had been converted to flats. My family lived on the top floor. My best friend, Viji, lived on the floor below. At the front of the house was a large verandah which jutted out from the rest of the building. From the front bedroom window of my flat I could see into Viji's verandah below, and my preferred method of communicating with her was to stick my head out of my window and to holler for her, until, no matter where she was within her flat, she heard me and came.

I remember clearly that when the idea settled into me that I would one day be a writer, I went to the front window and bellowed for Viji until she came.

"What?" she asked impatiently. I'd obviously interrupted something important, perhaps an exciting part in a book-she, too, was an avid reader.

"Guess what?" I said, all excited and earnest.

"What?"

"I'm going to be a writer when I grow up."

Viji looked irritably at me and clicked her tongue. "Yeah, I know that." Her tone said plainly: why are you telling me something so obvious?

I don't think I really considered how this wanting to be a writer fit with my other goal of becoming a doctor. At times, the writer's dream submerged almost completely-because I pursued the sciences in school—but at no time did it dissolve and disappear. It simply waited for the right moment to reappear.

And the ocean, the sound and energy of water lapping against the shore, which had so delighted me in my childhood, played a part in helping it come to fruition.

I was around thirty at the time, married with two children, and living in Prince Edward Island. My husband, Ian, and I, loved the beaches. Ian is a bona fide Islander-his ancestors were among the early settlers who came to PEI from Scotland. We used to escape to the beaches of the north shore of the Island as often as we could. It was our way of balancing and harmonizing our lives, putting things in perspective, and unwinding.

I remember this one visit. I was a full time stay at home mother. I had started a pottery studio in my basement and I still scribbled stories. I carried around a notebook in which I jotted down ideas, descriptions, fragments of conversations. I thought and talked a lot about being a writer, and I had done so for years, ever since I had decided not to study medicine after all, but somehow, I couldn't, or didn't, really manage to work steadily at it.

It seems that many of my life's significant decisions and insights come to me when I'm on the beach. Certainly it was the case this time. That particular beach on the north shore of PEI was within a few miles of where Maud Montgomery had been born over a hundred years ago, and closer still to where she'd lived with her grandmother from the age of two, when her own mother died. It may even have been one of the ones that she visited and walked on, or perhaps glimpsed from her grandmother's house in Cavendish. 
Walking along the firm sand at the water's edge, I began to talk about writing again, and wondered why I wasn't settling down to it. Why wasn't I able to overcome the inertia, or whatever block it was, that tripped and stalled me?

And Ian replied that sometimes we are afraid to embark on our dreams because we are afraid of failing. It's so much easier to be successful in our imaginations and daydreams, than to put it to the test in reality.

This really hit home. I realized it was true. I remembered something from one of the Anne books, Anne of the Island, where an indecisive character, Philippa Gordon, discovers a way to cure her indecision. She does this by projecting what she thinks she'd wish to have done when she is eighty. It struck me that I didn't want to wake up one day and find myself eighty, still lamenting and bemoaning about not writing, and wishing and wishing that I had started years ago. So it is around that time that I took my metaphorical dive off a tall tree, my leap of faith. That's when I began to really focus on my writing.

All the stories I've related are of specific echoes and images lodged within me, ones which played a pivotal role in my life and in my becoming a writer. Of course there are many others:

I'd like to mention my English teacher in Standard six, Miss Halegua, who read out Oliver Twist, who didn't let us disrupt the class, and who suggested that we keep a notebook in which to write down ideas and quotes, which I did.

I'd like to mention Zoe Bebbington—an unknown Colonial lady who conferred upon my school in Bombay a prize in her name for an essay competition, which, to my infinite surprise, I won one year. The title of my essay was Monday, and the gist of it was decrying school and the sadistic tendencies of the teachers. It was a tongue in cheek essay which I thought was somewhat predictable, boring and obvious, because if I could think of those things, anybody could. But when I won that competition, for the first time it occurred to me that something I thought and felt, that something I wanted to say, might possibly be of interest to other people. That it might have some small merit—and perhaps even be original.

I'd like to mention the kind librarian, with grey hair and dark circles under her eyes, who kept the library stocked with books at the Theosophical society across the road from my house in Bombay. She overlooked my lamentable tendency to be late returning books, and encouraged me to borrow more, and read and read and read.

I'd like to mention Dr. Metcalfe, a small, elderly man with gnarled arthritic hands, my microbiology professor in King's College in London, England, where I studied biology, who properly took the conc eit out of me by insisting that I write plainly and simply, and not pad my essays with flowery and irrelevant asides, which I did as a means of covering my ignorance.

I'd like to mention the wonderful old art of elocution, which was encouraged in my Bombay school. Elocution develops, I think, a keen ear for the cadences and rhythms of language as well 
as a love of language. I remember hours of listening to kids practise and then perform memorized pieces of poetry-mostly cautionary and didactic ones-fragments of which linger still.

I 've sketched many images here, from the mess and mass of experiences and thoughts and ideas and books in my life, and I've linked moments that influenced me to became a writer. But when I consider the echoes and images influencing the writers and people who influenced me, the frame of my story widens considerably.

Maud Montgomery, in writing the books that impacted so strongly on me, was in turn influenced by her favourite books and authors. She quotes Tennyson in her books, referring to his Lancelot and Elaine, one of the books in The Idylls of the King; she quotes Robert Browning, Alexander Pope, Wordsworth, as well as the Bible. Nineteenth Century literature appealed to her and she also read Walter Scott, Byron, Carlyle, whose influences, I think, are apparent in her writing, in her romantic portrayals of nature. She wove together their ideas, visions and interests with aspects of the society in which she lived, spiking her work with a wonderful sense of humour. She poked sly fun at the foibles of her community, writing about domestic comedy and drama, with all its safe rituals, unexpected traumas and disturbances, spinning together familiar jokes with the tragedies, both small and large, that occur in every family.

Louisa May Alcott, too, had her spheres of influence. Her father, Bronson Alcott, was part of the Transcendental Club of which Emerson and Thoreau were important members. Born in reaction to scientific rationalism, Transcendentalism emphasized the importance of intuition. It was a movement that proclaimed the spiritual unity of all living beings, and deeply honoured the natural world. Many of the Transcendentalist theories and ideas are close to those espoused in the ancient Indian spiritual texts, the Vedas, which were also the source of inspiration for the Theosophical Society, of which my grandparents were members.

It's a bit like the thigh bone is connected to the knee bone, is connected to the shin bone-on and on. The American Transcendentalists were influenced by the German Transcendentalists, whose doctrines are reflected in the work of Carlyle, Coleridge and Wordsworth, who also in turn influenced Lucy Maud Montgomery. Louisa May Alcott wove many of these philosophies along with her own life experiences into her books about the March family.

Such a web of ideas and influences moving back and forth. The echoes and images within L.M. Montgomery, Louisa May Alcott, and other favourite writers, are all manifest to a greater or lesser degree in their work. And if we trace it backwards, there are even wider sources of influence, inspiration and life experience impacting on those who impacted on Alcott and Montgomery.

These ideas and influences don't move in a tidy linear fashion, but rather they boomerang back and forth, in and out, in all directions, to create a web of stories with a web of sources. I heard somewhere that all the atoms of oxygen breathed in, and the molecules of carbon dioxide breathed out, have been breathed in and out by every living being who has ever inhabited this 
planet at any time. I'm not certain if this is true or not, but I like to think of stories, too, having that kind of universality. They reverberate within us all, ricochet back and forth, speaking to the common condition of being human, springing from that common condition of being human. They negate boundaries and barriers. If we trace these sources back far enough, perhaps we return to the first attempts at storytelling that may have occurred around fires outside caves; the first attempts by people trying, not just to comprehend, explain, and find the meaning of life, but also to express the delight and wonder echoing within their hearts. The first attempts at creating stories for the sheer joy of it. Faint echoes, perhaps, of that big bang which began all creation.

As a writer I've learned to honour the synchronicity of seemingly disconnected events, and to trust the juxtapositioning of what appear to be random thoughts and occurrences. And whether I tell the story of how I came to write, or an entirely fictional one, whether the experiences are real or imagined, still this one thing is constant-I aim to tell the truth.

It's a delightful paradox that writing fiction is, in a way, telling the truth through lies. One of the reasons I write fiction is because I firmly believe that the truth we tell through lies is often greater than when we stick to bald facts. But sometimes, sometimes the bald facts suffice-because truth can be stranger and neater than fiction.

So here are just two more to add to my story. The first one is simply this: my name, Rachna, an Indian name, means in Sanskrit, creation or literature. My mother doesn't know why they chose this name for me-just that one of my father's sisters suggested it.

And the second one concerns an incident, that occurred this past summer, while I was visiting PEI. My family and I now live in Ottawa, but as we have friends and family in PEI, and we desperately need to get a regular fix of our ocean, we visit the Island yearly. Usually, during the summer months, we avoid Cavendish, where Maud Montgomery lived, because we feel it has become commercialized and overly crowded and touristy. But this summer, we stopped off at a place I had not visited before. I expect that when I left PEI ten years ago, it may not have been open, or possibly I avoided it then, because I thought it was another exploitive gimmick.

I'm talking about the site of Montgomery's Cavendish home, the home she shared with her grandmother, and where she lived until 1911, when she was 36. It is in this house that she wrote Anne of Green Gables. The Green Gables house is not modelled after this, her home, but on another house belonging to a friend of hers. That Green Gables house is now part of the National Park in PEI, and tourists come from around the world to see it.

But the house I'm talking about, the site of Maud Montgomery's home in Cavendish, is just that - a site. The house itself is long gone. Distant cousins of hers, who still own the land, have opened it to the public. There are placards at intervals with information about the site, and with relevant excerpts from Montgomery's books and journals. All that remains is the red Island sandstone foundation, which was the cellar of her home; the long homestead lane down to the road; and many of the trees and views loved by Maud, including the apple orchard.

But before we entered the site, we had to purchase tickets from a small wooden bookstore nestled 
against a grove of trees. And when we went into that bookstore to get our tickets, I saw there, amongst the collection of books available for sale, my first book, My Mother is Weird, which was published by Ragweed Press on PEI, and which is available at many Island outlets. A young girl was holding it in her hands, eagerly turning the pages as she read it. She was oblivious to her surroundings.

Later, as I stood under what would have been Maud's gable window, where she wrote Anne of Green Gables, I gazed out at the fields and trees she would have seen, and felt somehow, not the presence of Maud Montgomery, but the memory of her passing there, echoes of her having lived and loved there. It was almost tangible, her love of that landscape, and I felt grief at her having to leave it—which she did when she married a minister, Ewan MacDonald, and moved to Ontario.

And strolling down the lane that Maud must have traversed so many times, heading to the cemetery where she is buried, it felt somehow fitting, almost like coming full circle, that I, the child who heard Anne of Green Gables in a classroom in India, should be here, where the author wrote it, and see a child reading one of my books. That I, carrying images from Maud Montgomery's books, came to Canada, and, encouraged and inspired by the openness and possibilities of the landscape and the culture, intertwined some of the landscapes and cultural traditions of India, along with those of Maud and Louisa-to create books containing echoes and images of the Canadian ethos and landscape in this particular moment of time.

In the words of Basho, the great 17th century haiku master:

The temple bell stops.

The sound keeps coming

Out of the flowers. 